\title{
CORRESPONDENCE
}

\section{Third wave of COVID-19 Epidemic in Pakistan}

Sara Mumtaz, Sana Gul

\begin{abstract}
Third wave of COVID-19 is thought to be intensifying in Pakistan in March 2021. It was confirmed by government officials that the spread was started from the areas where many Pakistanis from UK were residing. Genome sequencing of coronavirus by National Institute of Health, Pakistan revealed that it is UK strain that has started spreading in country. ${ }^{1,2}$ By March 25, 2021 confirmed cases of COVID were 640,988 with 37,985 active cases, 14,028 deaths and 588, 975 recoveries. ${ }^{3}$ An alarming situation is developing in the country again as mortality rate due to new strain in high. ${ }^{1}$ The situation of vaccination is not up to the need of country and Pakistani is lagging behind if we compare it with other countries like India. ${ }^{2}$ On February $1^{\text {st, }} 2021$ Pakistan received its first coronavirus vaccine made by Chinese company Sinopharm as a donation from Chinese military to Pakistan army. This vaccine was later contributed to the Pakistan national vaccine drive to provide it to health workers all over the country. ${ }^{4}$ Now Pakistan is also vaccinated the people over the age of 60 and has received more vaccines from China. ${ }^{5}$ However, we must be aware that COVID-19 is a highly infectious disease and scientists are yet not fully aware about the behavior of coronavirus. The best practice for the prevention and control of this virus is still relies on taking appropriate precautionary measures.
\end{abstract}

How to cite this: Mumtaz S, Gul S. Third wave of COVID-19 Epidemic in Pakistan. Life and Science. 2021; 2(2): 83-83. doi: http://doi.org/10.37185/LnS.1.1.198

This is an Open Access article distributed under the terms of the Creative Commons Attribution License (http://creativecommons.org/licenses/by/4.0), which permits unrestricted use, distribution, and reproduction in any medium, provided the original work is properly cited

Department of Biological Sciences

National University of Medical Sciences, Rawalpindi

Correspondence:

Dr. Sara Mumtaz

Assistant Professor, Biological Sciences

National University of Medical Sciences, Rawalpindi

E-mail: sara.mumtaz@numspak.edu.pk

Funding Source: NIL; Conflict of Interest: NIL

Received: Mar 30, 2021; Accepted: Mar 31, 2021

\section{REFERENCES}

1. https://tribune.com.pk/story/2289002/third-covid-19-wave-has-started-in-pakistan-confirms-asad-umar

2. https://www.dawn.com/news/1612114

3. https://covid.gov.pk/

4. https://www.thenews.com.pk/latest/786928-army-contributes-chinese-donated-vaccine-to-national-vaccine-drive

5. https://www.aa.com.tr/en/asia-pacific/pakistan-receives-2nd-batch-of-sinopharm-vaccine/2179427 